goner of AIASEA

Dupartint of ruturnd Recoureen

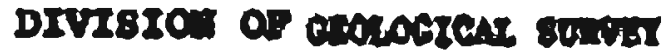

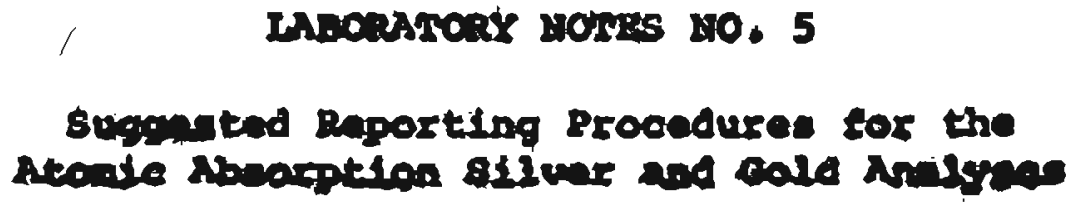

Ey

Paut 1. Andareon

College. Alarica

Xovambar 1968 


\section{SUCGESTED REPORTING PROCEDURES FOR THE ATOMIC ABSORPTION SILVER AND GOLD ANALYSES}

I N T R O D U C T I O N

In order that the resulte of our gold and silver analyses by atolaic absorption be consistent and valid the considerattons given below are thought to be useful as reporting procedures.

\section{CONS I DER A T I O N S}

By consulting the attached graph representing a typical analytical line for the range of 0.0 to 1.0 ppra of silver or gold, and accepting that reading the absorbence value to two significant figures is easily attained, reading the concentration value to two significant figures is valid. Therefore, in the range up to 1 ppm the regults should be reported to two decimal places of a ppm.

Though the above is true for reporting geochemical values where very amall changes in concentration are significant. a different reporting procedure for ore and sub-ore type samples, where dollar values are more important, is required. In the case of these samples the ppm values are converted to troy ounces per ton by dividing the ppm value by 34.3 which is the number of ppm per troy ounce. In this case, as a reasonable cut off limit, and to be consistent with fire assay, below $0.034 \mathrm{ppm}(0.001 \mathrm{oz} / \mathrm{ton})$ in the oarmple is termed Nil, 0.034 to $0.34 \mathrm{ppm}(0.01 \mathrm{oz} /$ ton) is termed Trace. Values above 0.34 ppm are converted to troy ounces per ton and that value reported.

Considering that in the range below 1 ppra there are two significant figures in the concentration value and three algnificant figures in the conversion value the ounces per ton figure could be reported to two significant figures; at the minimum value, $\frac{0.34}{34.3}=0.010$ with the final zero significant. Because these are ore samples the third place has little "econonic significance" and it is suggested that the values in troy ounces per ton be reported to only two decinal places. Reporting to two decimal places is valid to 10 ounces per ton. Ten ounces per ton to 100 ounces per ton reporting to one decimal place is valld, and no decimal places at 100 ounces per ton and above.

The table on the following page outlines the proposed reporting procedures. 
Gold-SLlver concentration

in the Sample as Determined by Atonic ADsorption Analyses

$$
\begin{aligned}
& 0.0 \text { to } 0.034 \\
& 0.035 \text { to } 0.34 \\
& 0.35 \text { to } 0.99 \\
& 1.00 \text { to } 9.99 \\
& 10.0 \text { to } 99.9 \\
& 100 \text { to } 343 \\
& 344 \text { to } 3426 \\
& \text { above } 3426
\end{aligned}
$$

\section{Geochernical keporting in Parts Per Milition}

2 significant figures*

2 significant Eigurea

2 significant figures

3 significant figures

3 significant figures

3 significant figures

3 significant figures**

3 significant figures
Ore and Sub-ore Samples in Troy Ounces Per Ton, Divide PPM by 34.3

\section{Nil}

\section{Trace}

2 decimal places, 1e, 0.01 to 0.03 oz/ton

2 decimal places, ie, 0.03 to $0.28 \mathrm{oz} / \mathrm{ton}$

2 decinal places, ie, 0.28 to $2.91 \mathrm{oz} / \mathrm{ton}$

2 decimal places, ie, 2.91 to $9.99 \mathrm{oz} / \mathrm{ton}$

1 decimal place, ie, 10.0 to $99.9 \mathrm{oz} / \mathrm{ton}$

0 decimal place, ie, 100

* Significant figures do not include those zeros used only to establish the position of tire decimal point, eg, 0.0028 has 2 significant figures, 28.

* Wrice a 4 digit number with only 3 significant figures by writing the last digit as a ginall superscript, eg, 3426 is written as 3426 , and explain the notation on the report sheet. 
